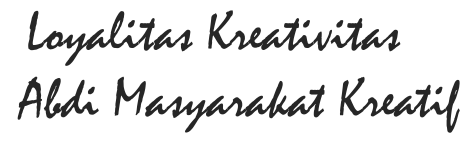

P-ISSN 2722-2101, E-ISSN 2722-4201

Program Studi Ekonomi Manajemen Universitas Pamulang

Jurnal LOKABMAS Kreatif Vol. 01, No. 03, Hal. 16-24

Email:jurnalkreatif.manajemen@gmail.com

\title{
PEMBERDAYAAN IBU-IBU PKK MELALUI PELATIHAN PENINGKATAN POTENSI DENGAN MOTIVATION TRAINING SEBAGAI UPAYA MEMBANGKITKAN PEREKONOMIAN MASYARAKAT DI KELURAHAN SAWAH CIPUTAT, TANGERANG SELATAN
}

\author{
Siti Aprilliani, Ani Meryati, Indri Kharisma, Hasanudin, Ardi Bachtiar \\ Dosen Ekonomi Fakultas Ekonomi Universitas Pamulang

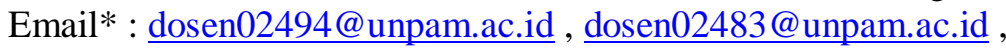 \\ dosen02474@unpam.ac.id, dosen02482@unpam.ac.id, dosen02475@unpam.ac.id
}

\begin{abstract}
ABSTRAK
Kegiatan pegabdian kepada masyarakat ini bertujuan untuk mensosialisasikan dan memberikan penyuluhan terkait pengetahuan bagaimana cara memaksimalkan penjualan melalui pemasaran online yaitu dengan mempromosikan produk di media sosial. Adapun metode yang dilakukan berupa penyampian materi dalam bentuk teori presentasi dan praktik/penerapan pembuatan akun media sosial dan cara promosinya.

Metode kegiatan yang digunakan adalah bekerjasama dengan ibu-ibu PKK (Pemberdayaan Kesejahteraan Keluarga) Kelurahan Sawah Ciputat, kegiatan dilaksanakan di Aula Kelurahan Sawah Ciputat dan memberikan solusi sesuai dengan permasalahan yang dihadapi yaitu memberikan pelatihan dalam bentuk materi dan praktek yang bertujuan mengembangkan kemampuan untuk meningkatkan pemasaran secara online dengan menggunakan media sosial bagi para peserta dari Ibu-ibu PKK guna untuk dapat membantu perekonomian Masyarakat di lingkungan.

Hasil kegiatan menunjukkan bahwa sebelum pelaksanaan PKM, para anggota PKK sudah mengenal beberapa jenis media sosial yang terkait dengan pemasaran produk lewat media online yang berada didalam suatu aplikasi online, tetapi mereka hanya mengetahui jenis-jenis media sosialnya saja, mereka belum bisa membuat akun dan melakukan publikasi produk ke dalam akun media sosial tersebut. Namun setelah pelaksaan kegiatan diketahui para peserta dari PKK tersebut dapat memahami dasardasar pembuatan akun dengan cara memilih social media yang sesuai dengan produk/jasa yang akan mereka pasarkan agar dapat mencapai sasaran yang tepat.
\end{abstract}

\section{Kata kunci : Pemberdayaan ibu-ibu PKK, Motivation Training, Media social}

\section{ABSTRAC}

This community service aims to socialize and provide counseling related to knowledge on how to maximize sales through online marketing by promoting products on social media. The method used in the form of delivery of material in the form of presentation theory and practicelapplication of making social media accounts and how to promote them.

The method of activity used in collaboration with PKK (Pemberdayaan Kesejahteraan Keluarga) Ciputat Sawah Village, the activities are carried out in the Ciputat Sawah Village Hall and provide solutions in accordance with the problems faced 
by providing training in the form of materials and practices aimed at developing capabillities to improve marketing online by using social media for participants from PKK ladies to be able to help the community's economy in the neighborhood.

The results of the activity showed that prior to the implementation of PKM, the participants of the PKK had already known several types of social media related to marketing products through online media that were in an online application, but they only knew the types of social media, they cannot create an account and publish product to the social media account. However, after implementation of the activity it was found out that the participants of the PKK could understand the basics of creating an account by closing social media that was appropriate to the product / service they were going to market in order to achieve the right target.

\section{Keywords : PKK, Motivation Training, Social Media}

\section{PENDAHULUAN}

Pemberdayaan dapat disamakan dengan istilah pengembangan atau pembangunan. Pemberdayaan berasal dari kata daya yang berarti kekuatan. Jadi pemberdayaan berarti upaya untuk memperoleh kekuatan dalam menguatkan diri dari segala bentuk penindasan. Pemberdayaan adalah upaya untuk membangun kemampuan masyarakat, dengan mendorong, memotivasi, membangkitkan kesadaran akan potensi yang dimiliki dan berupaya untuk mengembangkan potensi itu menjadi tindakan nyata. Pemberdayaan masyarakat pada dasarnya merupakan proses untuk membuat masyarakat menjadi berdaya. Setiap anggota masyarakat dalam sebuah komunitas sebenarnya memiliki potensi, gagasan serta kemampuan untuk membawa dirinya dan komunitasnya untuk menuju ke arah yang lebih baik, namun potensi itu terkadang tidak bisa berkembang disebabkan faktor-faktor tertentu. Untuk menggerakkan kembali kemandirian masyarakat dalam pembangunan di komunitasnya, maka diperlukan dorongan-dorongan atau gagasan awal untuk menyadarkan kembali peran dan posisinya dalam kerangka untuk membangun masyarakat madani. Proses penyadaran masyarakat tersebut dilakukan melalui konsep-konsep pengembangan kapasitas. Pengembangan kapasitas masyarakat adalah bentuk dari upaya pengembangan pengetahuan, sikap dan keterampilan masyarakat agar dapat berperan serta aktif menjalankan pembangunan secara mandiri dan berkelanjutan.

Fungsi ekonomi dalam keluarga sangatlah penting, karena ekonomi merupakan kegiatan untuk membuat anggota keluarga memiliki life skill dan mampu menghasilkan pendapatan ekonomi keluarga. Untuk itu sangatlah penting kegiatan wirausaha berskala keluarga diterapkan pada masyarakat, dengan memperhatikan faktor kondisi keuangan keluarga dan tempat usaha. Ekonomi rumah tangga berasal dari pemikiran kreatif dari anggota keluarga untuk meningkatkan taraf hidup keluarga agar lebih baik dan sejahtera.

Dalam kehidupan nyata seringkali perempuan kurang mampu berperan aktif dalam ekonomi keluarga, sehingga perempuan hanya bekerja sebagai ibu rumah tangga dan bergantung dengan hasil pendapatan suami. Pekerjaan perempuan dalam rumah tangga menyebabkan perempuan dianggap 
sebagai penerima pasif pembangunan. Dalam rangka mendorong partisipasi perempuan dalam pembangunan perlu terus makin dikembangkan kegiatan perempuan dalam meningkatkan kesejahteraan keluarga antara lain melalui organisasi Pemberdayaan Dan Kesejahteraan Keluarga PKK. PKK merupakan wadah bagi perempuan untuk mengembangkan kemampuan dan potensi yang dimiliki perempuan agar secara mandiri mempunyai keterampilan dan keahlian dalam mengatasi masalah yang mereka hadapi secara mandiri melalui peningkatan kapasitas dan kualitas hidup. Kesejahteraan keluarga menjadi tujuan utama PKK. Hal ini dikarenakan keluarga merupakan unit terkecil masyarakat yang akan berpengaruh besar terhadap kinerja pembangunan.

Kelurahan sawah merupakan kelurahan yang terletak di kecamatan ciputat kabupaten Banten kota Tangerang Selatan. kelurahan sawah memiliki kelompok ibu-ibu yang tergabung dalam PKK (Pembinaan Kesejahteraan Keluarga). Ibu-ibu yang tergabung dalam PKK memiliki latar belakang yang beragam antara lain lulusan SD, SLTP, dan SLTA sebagian besar adalah ibu rumah tangga dengan kondisi ekonomi menengah kebawah. Kebutuhan pokok sehari-hari yang semakin meningkat mengharuskan ibuibu yang tergabung di PKK juga bekerja sebagai ibu rumah tangga. kondisi ini terjadi karena tidak adanya lapangan pekerjaan yang tersedia, selain itu ibuibu PKK Kelurahan sawah memiliki potensi yang memadai untuk dikembangkan menjadi usaha sampingan.

Walaupun demikian, tim pengabdian mengasumsikan bahwa jika ibu-ibu PKK dibina dan dilatih maka pengetahuan dan potensi akan dapat dikembangakan dan ditingkatkan sehingga dapat meningkatkan kesejahteraan keluarga. Dan disini kami menawarkan untuk mengaktivasi potensi kreatifitas yang telah dimilki ibu-ibu PKK kelurahan Sawah dengan motivation training and skill pemasaran yang menarik ( negosiasi, mencari jaringan dagang, berjualan tanpa modal) serta membantu follow-up manajemen pemasaran dengan produk yang kami rekomendasikan yaitu berupa fashion, Kesehatan, skincare dan makanan.

Semua produk yang telah direkomdasikan tersebut akan menjadi referensi bagi ibu-ibu PKK untuk menjadi supplier, sehingga dapat membantu ibu-ibu PKK untuk dapat berjualan secara online dan offline tanpa menggunakan modal. Sehingga ibu-ibu PKK yang mempunya skill untuk berjualan hanya fokus kepada promosi saja dengan menggunakan social media. Selain itu ibu-ibu PKK juga akan diberikan pembelajaran atau training mengenai strategi promosi melalui social media, berupa upload produk dan pemberian keterangan mengenai produk yang akan di pasarkan di media sosial.

Untuk itu, kami Dosen Universitas Pamulang dan mahasiswa akan mengadakan Pengabdian Kepada Masyarakat (PKM) bekerjasama dengan Pembinaan Kesejahteraan Keluarga (PKK) Kelurahan Sawah Ciputat untuk memberikan pelatihan kepada Ibu-ibu PKK di Keluirahan Sawah Ciputat dengan judul "Pemberdayaan Ibu-ibu PKK Melalui Pelatihan Peningkatan Potensi Dengan Motivation Training Sebagai Upaya Membangkitkan Perekonomian Masyarakat di Kelurahan Sawah Ciputat". 


\section{Perumusan Masalah}

1. Bagaimana memberikan pemahaman kepada para peserta mengenai jenis-jenis sosial media yang tepat untuk melakukan promosi kepada ibu-ibu PKK di kelurahan Sawah Ciputat?

2. Bagaimana memberikan pengarahan kepada para peserta untuk meng-upload gambar produk yang akan dijual kepada Ibu-ibu PKK Kelurahan Sawah Ciputat?

3. Bagaimana memberikan pengarahan kepada para peserta cara memilih supplier yang tepat kepada Ibu-ibu PKK Kelurahan Sawah Ciputat?

4. Bagaimana memberikan pelatihan kepada para peserta mengembangkan pemasaran produk secara online dengan teknik promosi di media sosial kepada Ibu-ibu PKK Kelurahan Sawah Ciputat?

\section{Tujuan Pengabdian Kepada Masyarakat}

1. Untuk memberikan pemahaman kepada para peserta mengenai jenisjenis sosial media kepada Ibu-ibu PKK Kelurahan Sawah Ciputat

\section{TINJAUAN PUSTAKA}

\section{Pengertian Teknologi Informasi}

Pengertian Teknologi Informasi Menurut Williams dan Sawyer (2003) adalah Teknologi yang menggunakan komputasi (komputer) dengan jalur komunikasi kecepatan tinggi yang membawa data, suara, dan video. Menurut Mc. Keown (2007) Pengertian Teknologi Informasi adalah mengacu pada semua bentuk teknologi yang digunakan untuk bisa menciptakan, menyimpan, mengubah dan juga menggunakan informasi tersebut dalam semua bentuknya. Sedangkan Menurut
2. Untuk memberikan pengarahan kepada para peserta cara mengupload gambar yang akan di jual kepada Ibu-Ibu PKK Kelurahan Sawah Ciputat.

3. Untuk memberikan pengarahan kepada para peserta cara memilih Suplier yang tepat kepada Ibu-ibu PKK Kelurahan Sawah Ciputat?

4. Untuk memberikan pelatihan kepada para peserta mengembangkan pemasaran produk secara online dengan teknik promosi di media sosial kepada Ibu-ibu PKK Kelurahan Sawah Ciputat?

\section{Manfaat Pengabdian Kepada Masyarakat}

1. Semua peserta dapat menambah wawasan dan pemahaman mengenai Penjualan Secara online

2. Semua peserta dapat memilih Supplier yang tepat sesuai dengan unit usahanya.

3. Dengan penerapan Stategi Promosi yang tepat di Media Sosial dapat menjangkau pasar yang lebih luas sehingga profit usaha yang dihasilkan maksimal.

Martin (2009) Pengertian teknologi informasi adalah teknologi yang tidak hanya pada teknologi komputer (perangkat keras dan perangkat lunak) yang akan digunakan untuk memproses dan menyimpan informasi, melainkan mencakup teknologi komunikasi untuk mengirim atau menyebarluaskan informasi.

Berdasarkan beberapa pengertian sistem informasi menurut para ahli tersebut dapat disimpulkan sistem informasi merupakan suatu kombinasi yang teratur yang terdiri dari komponen-komponen yang dibuat oleh manusia yang bila eksekusi akan 
menyediakan informasi untuk mendukung pengambilan keputusan. Mengenai hal tersebut ada sistem yang sering digunakan dalam dunia usaha untuk menjual barang dan hasil produksinya yaitu disebut Sosial Media. Pengertian Media Social dalam ECommerce

Seiring dengan pertumbuhan $e$ commerce, media sosial dilirik sebagai kenal komunikasi antara pelaku usaha dan konsumen. Sebagaimana diketahui bahwa perkembangan teknologi informasi telah membuka jalan bagi peluang-peluang baru dalam binsis, melalui $e$-commerce, tidak saja memperluas arus barang dan jasa, namun juga menciptakan kesempatan bagi individu untuk terlibat sebagai pelaku usaha.

Media social yang digunakan oleh pelauku usaha daman E-commerce beragam seiring dengan perkembangan teknologi informasi itu sendiri, Website merupakan media yang banyak dipilih oleh pelaku usaha untuk menawarkan barang / jasa. Namun seiring perkembangan teknologi informasi dan perubahan perilaku pengguna internet, media social mengambil peran penting dalam pemasaran barang / jasa. Menurut survey internet 2016 oleh APJII (Asosasi Penyelenggara Jasa Internet Indonesia ), penggunaan media social sebagain sarana berdagang menduduki peringkat ke-2 tertinggi setelah penggunaan media social sebagai alat berbagi informasi.

Jika kita dapat memanfaatkan media social dengan baik dan benar maka media social akan menjadi pundi-pundi keuntungan dan peluang bagi pelaku usaha karena dengan cara mempromosikan produk yang akan di jual melalui media social akan dengan lebih cepat menyebar ke banyak account media social dan dapat di lihat oleh orang banyak. Selain penggunaan media social yang gratis kita juga bisa mencari informasi mengenai supplier yang dapat membantu pelaku usaha untuk menambhakan beberpa jenis produk yang akan dijual.
Dari sudut hukum perlindungan konsumen, penggunaan media social sebagai tempat mempertemukan pelaku usaha dan konsumen memiliki catatan sendiri. Eksistensi pelaku usaha merupakan catatan utama terkait penggunaan media sosial dalam e-commerce. Tidak termasuk dalam lingkup isu ini adalah social media sebagai kepanjangan tangan dari suatu website. Eksistensi tersebut sangat penting bagi konsumen ketika konsumen memiliki keluhan terhadap transaksi atau barang yang dibeli. Terlebih apabila metode pembayaran yang digunakan adalah bayar dimuka. Pembayaran telah dilakukan, namun barang tidak juga dikirimkan, atau barang yang dikirimkan tidak sesuai dengan pemesanan. Eksistensi pelaku usaha terasa menjadi semakin penting Ketika konsumen mengalami kerugian akibat mengkonsumsi barang yang di pedagangkan oleh pelauku usaha tersebut.

Ketika konsumen bermaksud untuk meminta pertanggung jawaban pelaku usaha, account media social pelaku usaha tersebut sudah tidak aktif dan pelaku usaha sudah tidak dapat dihubungi, UU ITE memang telah meletakan kewajiban bagi pelaku usaha untuk memberikan informasi kepada konsumen, tidak saja mengenai barang yang dijual, namun juga mengenai identitas pelaku usaha. Namun dengan kemudahan untuk membuka atau menutup account sebuah social media, hal tersebut rasanya tidak memberikan perlindungan yang cukup. Sehingga untuk mengetahui kredibilitas dari pelaku usaha, konsumen hanya dapat mengandalkan informasi-informasi terkait kualitas barang dan performa pelaku usaha. Selanjutnya dengan melihat pada potensi penggunaan social media sebagai media transaksi dalam e-commerce, maka perlu untuk dikaji Kembali upaya-upaya yang dapat dilakukan terutama dari sisi regulasi dan peningkatan awareness konsumen agar dampak positif dari e-commerce tidak 


\section{Loyalitas Kreativitas Aldi Masyarakat Kreatif}

P-ISSN 2722-2101, E-ISSN 2722-4201

Program Studi Ekonomi Manajemen Universitas Pamulang

Jurnal LOKABMAS Kreatif Vol. 01, No. 03, Hal. 16-24

Email:jurnalkreatif.manajemen@gmail.com

menjadi berkurang dengan adanya

kelemahan-kelemahan tersebut.

\section{Realisasi Pemecahan Masalah}

Dari uraian analisis situasi, maka dapat dibuat kerangka pemecahan masalah yang dihadapi sebagai berikut :

1. Memberikan pemahaman kepada para peserta mengenai pemilihan Media Social yang tepat kepada Ibu-ibu PKK Kelurahan Sawah Ciputat.

2. Memberikan pengetahuan kepada para peserta mengenai praktek penggunaan media social kepada ibu-ibu PKK Sawah Ciputat.

3. Memberikan pelatihan kepada para peserta dalam mengembangkan pemasaran produk secara online dengan strategi promosi di media social Setelah mengikuti kegiatan pelatihan para peserta dari PKK Kelurahan Sawah Ciputat dapat memahami dasar-dasar pembuatan akun, mengetahui cara memilih, merancang dan membuat Sosial Media yang sesuai dengan produk atau jasa yang akan mereka pasarkan agar dapat mencapai sasaran yang tepat sehingga bisa memaksimalkan keuntungan dari usaha tersebut.

\section{Khalayak Sasaran}

Yang menjadi sasaran dalam kegiatan PKM ini adalah anggota ibu-ibu PKK Kelurahan Sawah Ciputat yang berjumlah 35 orang yang mengikuti pelatihan terkait dengan perancangan dan penerapan E-marketplace untuk Usaha Kecil dan Menengah

\section{Tempat dan Waktu Pelaksanaan}

Kegiatan pengabdian kepada masyarakat (PKM) yang dilakukan oleh dosen prodi Manajemen Universitas Pamulang ini dilaksanakan pada : Tempat : Kelurahan
Sawah Jl. Cendrawasih RT001/001

Ciputat - Tangerang Selatan

Waktu : Tanggal 20-21 Mei 2020

\section{Metode Kegiatan}

Metode kegiatan yang digunakan kepada ibu-ibu PKK Kelurahan Sawah Ciputat adalah berupa penyuluhan dan simposium, selanjutnya mereka akan diberikan sesi tanya jawab tentang masalah yang dihadapi baik sifatnya pribadi maupun umum.

Untuk menghadapi permasalahan di atas dengan menggunakan berbagai melode, diantaranya Metode dalam kegiatan ini merupakan pemberian teori dan langkah-langkah membangun usaha di E-comerce salah satunya adalah Media Sosial, dengan melalui beberapa tahapan, adapun tahapannya yaitu:

1. Tahap persiapan, tahapan ini dilakukan terlebih dahulu seperti pemantapan dan penentuan lokasi dan sasaran, dalam tahapan ini meliputi Tahap Survey Awal yaitu pada tahap ini dilakukan peninjauan dan survey langsung di lapangan untuk memperoleh dan mengumpulkan informasi yang dibutuhkan. Dari hasil tahapan ini, proses pemasaran dan jual beli masih dilakukan secaara manual seperti off store dan pembukuaanya juga diproses secara manual.

2. Tahapan pemberian teori, tahapan ini akan menjelaskan konsep pengabdian kepada Masyarakat yang berupa penyuluhan kewirausahaan disertai pembelajaran mengenai strategi pomosi dan cara berjulan tanpa modal dalam wadah komunitas ibu-ibu PKK Kelurahan Sawah. 
3. Tahapan melihat Pasar, tahapan ini memiliki tujuan untuk menyiapkan produk yang akan dijual sehingga akan disesuaikan dengan nama toko, disamping itu juga bertujuan untuk memberikan rekomendasi produk yang memuliki potensi nilai jual tinggi di pasar

4. Tahap pemberian teori, tahap ini akan menjelaskan terkait keuntungan dan kelebihan proses usaha menggunakan Sosial Media, teori ini di dapat dari pengalaman sendiri dan studi literatur yaitu dengan mencari teori dari berbagai sumber yang berhubungan dengan Promosi melalui media sosial.

5. Tahap perancangan usaha, tahap ini dilakukan setelah persiapan produk dan peralatan lengkap serta penentuan media sosial. Tahap ini juga dilaksanakan setelah semua peserta memiliki produk yang akan di jual, sehingga akan mempermudah pada proses tahap selanjutnya, dengan kata lain pada tahapan ini adalah memilih e-commerce yang tepat. Pada tahapan ini juga, dilakukan pilihan akan kebutuhan sistem, maka secara otomatis telah melakukan sistem yang baik, yang akan digunakan dalam perancangan dan pembangunan sistem E-commerce.

6. Proses tanya jawab, tahap ini bertujuan apabila ada hal yang harus di diskusikan terlebihdahulu sebelum implementasinya, tahap ini juga berlangsung saat proses implementasi berlangsung, permasalah pada masing-masing e-commerce juga tidak sama, sehingga perlu analisa lebih misal permasalahan di Instragram akan berbeda dengan permasalahan yang ada di facebook, berikut dengan e-commerce lainnya.

7. Tahap penerapan usaha, tahapan ini adalah implementasi dari teori dan sekaligus pembuatan toko di $e$ commerce Dengan tahapan terakhir ini diharapkan semua peserta yang sudah memiliki produk dan tidak (khusus untuk yang jadi dropshiper) akan mengimplementasikan semua tahapan diatas, sehingga akan di sesuaikan dengan masing-masing unit usaha atau produk yang dimiliki. Dari semua tahapan-tahapan diatas juga, semua e-commerce tidak sama sehingga penentuan pemilihan $e$ commerce mempengaruhi tahapan selanjutnya. Disamping itu, melakukan deteksi masalah terhadap sistem usaha yang masih dilakukan secara manual yaitu dengan melakukan perumusan-perumusan masalah apa saja yang dapat menjadi kendala pada sistem usaha ini, sehingga dapat diketahui permasalahannya. Setelah dilakukan deteksi masalah yang ada tersebut maka mulailah dilakukan tahapan yang sesuai dengan masalah yang terjadi

\section{HASIL DAN PEMBAHASAN}

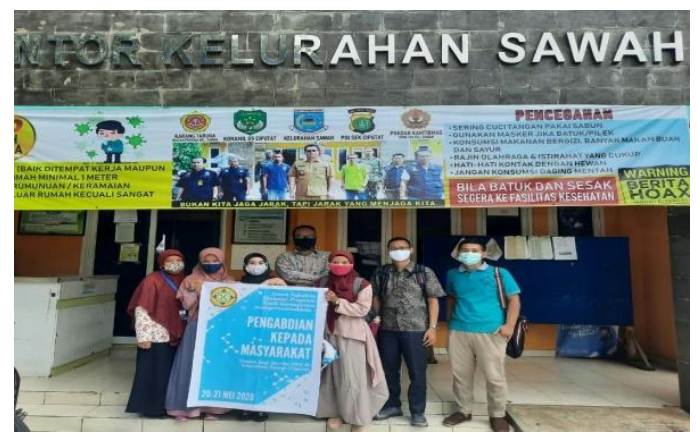

Gambar 4.1

Foto Kegiatan 


\section{Loyalitas Kreativitas Aldi Masyarakat Kreatif}

P-ISSN 2722-2101, E-ISSN 2722-4201

Program Studi Ekonomi Manajemen Universitas Pamulang

Jurnal LOKABMAS Kreatif Vol. 01, No. 03, Hal. 16-24

Email:jurnalkreatif.manajemen@gmail.com

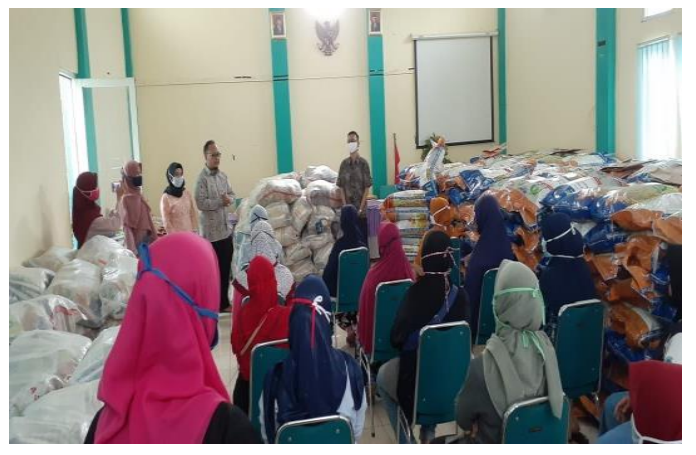

Gambar 4.2

\section{Penyampaian Materi}

E-commerce juga bisa menjadi solusi untuk mengatasi permasalahan yang di uraikan dalam pendahuluan maka dirancanglah suatu aplikasi e-commerce, yang diharapkan dapat menjadi tempat bagi customer maupun supplier dalam memasarkan dan mencari produk yang dibutuhkan. E-commerce ditujukan untuk menjadi tempat pertemuan antara pihak supplier-customer baik dalam memasarkan maupun mencari produk yang dibutuhkan. Penggunaan teknologi atau e-commerce ini diharapkan dapat memberikan manfaat yang besar terhadap para pelaku usaha atau bisnis yang kompetitif, para pelaku yang dapat bersaing dalam kompetisi adalah para pelaku usaha yang mampu mengimplementasikan teknologi dalam usahanya. Salah satu jenis

\section{KESIMPULAN DAN SARAN}

Pelaksanaan kegiatan Pengabdian Kepada Masyarakat oleh Lembaga Penelitian dan Pengabdian Masyarakat (LPPM) Universitas Pamulang yang dilakukan oleh dosen-dosen program studi Manajemen telah berjalan dengan lancar dan mendapat sambutan hangat dari tempat pelaksanaan kegiatan ini yaitu Kepala Kelurahan Sawah Ciputat. Harapan kami dengan pengabdian ini dapat menambah ilmu yang bermanfaat dalam implementasi dalam hal meningkatkan persaingan bisnis adalah dengan menggunakan e-commerce salah satunya adalah media sosial untuk memasarkan berbagai macam produk atau jasa, baik dalam bentuk fisik maupun digital. Dengan ini $e$ commerce didefinisikan sebagai proses pembelian dan penjualan antara dua belah pihak di dalam suatu perusahaan dengan adanya pertukaran barang, jasa atau informasi melalui media internet (Indrajit, 2001).

Hasil kegiatan ini menunjukkan bahwa sebelum pelaksanaan Pengabdian Kepada Masyarakat (PKM), para peserta dari Pemberdayaan Kesejahteraan Keluarga (PKK) sudah mengenal beberapa jenis media sosial, yang terkait dengan pemasaran produk lewat media online, akan tetapi mereka hanya mengetahui jenis-jenis Media sosial nya saja, mereka belum bisa membuat akun dan melakukan publikasi produk ke dalam akun media sosial tersebut, disamping itu juga para peserta tidak mengetahui potensi berjualan produk secara online tersebut. Namun setelah pelaksaan kegiatan diketahui para peserta dari ibu-ibu PKK dapat memahami dasardasar pembuatan akun dengan cara memilih media sosial yang sesuai dengan produk atau jasa yang akan mereka pasarkan agar dapat mencapai sasaran yang tepat sehingga bisa memaksimalkan keuntungan dari usaha tersebut

penyuluhan perancangan dan penerapan media sosial untuk melakukan promosi.

Dalam laporan kegiatan ini mungkin banyak kekurangan yang ada, untuk itu kami berharap masukan dan kritikan dalam rangka perbaikan untuk kegiatan-kegiatan pengabdian masyarakat di masa yang akan datang. Semoga kegiatan pengabdian masyarakat ini dapat bermanfaat bagi masyarakat sekitar lingkungan Universitas Pamulang dan lainnya. 


\section{Loyalitas Kreativitas Aldi Masyarakat Kreatif}

P-ISSN 2722-2101, E-ISSN 2722-4201

Program Studi Ekonomi Manajemen Universitas Pamulang Jurnal LOKABMAS Kreatif Vol. 01, No. 03, Hal. 16-24

Email:jurnalkreatif.manajemen@gmail.com
Akhirnya, kami mengucapkan terima kasih kepada seluruh pihak yang telah mendukung kegiatan yang kami laksanakan

\section{DAFTAR PUSTAKA}

Indrajit, Ricardus. 2001. E-Commerce Kiat dan Strategi di Dunia Maya. Jakarta: PT Elex Media Komputerindo

Iyas, Implementasi Sistem Penjualan Online Berbasis E-Commerce Pada Usaha Rumah Griya Unik Wanita, UIN Syarif Hidayatullah Jakarta, 2011.

Alma, Buchari. 2010. Kewirausahaan. Bandung: Alfabeta

Kasmir. 2006. Kewirausahaan Edisi 1. Jakarta: Rajagrafindo Persada

Pasaribu, V. L. D., Susanti, F., \& Hartuti, E. T. K. (2019). Memotivasi Siswa dan Siswi SMK Letris Indonesia di Dalam Menentukan Pilihan Untuk Melanjutkan Pendidikan Atau Bekerja Setelah Lulus Sekolah. Jurnal Pengabdian Dharma Laksana, 1(2), 161172.

Pasaribu, V. L. D., Elburdah, R. P., Sudarso, E., \& Fauziah, G. (2020). PENGGUNAAN MANAJEMEN WAKTU TERHADAP PENINGKATAN PRESTASI BELAJAR DI SMP ARAISIYAH. Jurnal ABDIMAS Tri Dharma Manajemen, 1(1).

Pasaribu, V. L. D., Agrasadya, A., Shabrina, N., \& Krisnaldy, K. (2020). MENJADI ENTERPRENEUR MUDA YANG MEMILIKI JIWA LEADERSHIP UNTUK MENGHADAPI MASA DEPAN. Abdi Laksana, 1(1).

Pasaribu, V. L. D., Sulaiman, S., Sutiman, S., Thaharudin, T., \& Purnomo, B. Y. (2020). dan kami mohon maaf apabila dalam pelaksanaan dan tulisan ini banyak ditemukan kekurangan.
PENGENALAN LETAK POSYANDU TERDEKAT DIKELURAHAN PISANGAN DENGAN MANAJEMEN PEMASARAN REVOLUSI 4.0 UNTUK MENINGKATKAN PENGETAHUAN MASYARAKAT LETAK DAN FUNGSI POSYANDU TERDEKAT PADA KELURAHAN PISANGAN. DEDIKASI PKM, 1(1), 105-110.

Priadi, A., Pasaribu, V. L. D., Virby, S., Sairin, S., \& Wardani, W. G. (2020). PENGUATAN EKONOMI KREATIF BERBASIS SUMBER DAYA DESA DIKELURAHAN REMPOA. Abdi Laksana, 1(3), 356-358.

Ruslan, D., \& Budiarta, K. (2017). Pemberdayaan Ekonomi Produktif Masyarakat Miskin di Kota Medan. Jurnal Pembangunan Perkotaan, 5(2), 91-95

Williams dan Sawyer. 2003.Using Information Technology: A Practical Introduction to Computers and Communications.London: CareerEducation.

McKeown, P. G. 2007. Information Technology and The Networked Economy. Pennsylvania: Course Technology

Martin, E.Wainright. et.al. 2009. Managing Information Technology What Managers Need to Know. Pearson Educational International. New Jersey. 